\title{
30. SECONDARY MINERALS IN BASALT FROM THE COSTA RICA RIFT, HOLES 501 AND 504B, DEEP SEA DRILLING PROJECT LEGS 68, 69, AND 701
}

\author{
Victor B. Kurnosov, Igor V. Kholodkevich, and Valerii M. Chubarov, Far-East Geological Institute, \\ Vladivostok, U.S.S.R. \\ and \\ Alla Ya. Shevchenko, Institute of Oceanology, U.S.S.R. Academy of Sciences, Moscow, U.S.S.R.
}

\begin{abstract}
Basalt samples recovered during DSDP Legs 68, 69, and 70 from a 550-meter-thick section in two holes near the Costa Rica Rift (Holes 501 and 504B) were found to contain the following secondary minerals: trioctahedral and dioctahedral smectite, chlorite, mixed-layer clays, talc, hematite, pyrite, foujasite, phillipsite, analcime, natrolite, thomsonite, gyrolite, aragonite, calcite, anhydrite, chalcocite, Fe-hydrosilicate, okenite, apophyllite, actinolite, cristobalite, quartz, and magnesite. A less positive identification of bismutite was made. A mineral rich in $\mathrm{Mn}$ and minerals with strong reflections at $12.9 \AA$ and $3.20 \AA$ remain unidentified.

Trioctahedral smectite replaces glass and olivine in the basalt groundmass. The other secondary minerals occur in veins. The distribution of the secondary minerals in the basalt section shows both hydrothermal and oxidizing-nonoxidizing zonation.

Most of the secondary minerals formed under alkaline, nonoxidizing conditions at temperatures up to $120^{\circ} \mathrm{C}$. An acidic regime probably existed in the lowest portion of basalt. Oxidative diagenesis followed nonoxidative diagenesis in the upper part of the section. Oxidative diagenesis is characterized by the absence of celadonite, rare occurrences of dioctahedral smectite, and widespread hematite and phillipsite.
\end{abstract}

\section{INTRODUCTION}

Secondary minerals in basalts drilled from Holes 501 and 504B near the Costa Rica Rift were identified and analyzed, and an attempt was made to infer the physical and chemical conditions under which they formed.

\section{METHODS}

Secondary minerals were identified chiefly by X-ray diffraction analysis. Infrared spectral analysis, electron microscopy, scanning electron microscopy (SEM), and electron diffraction were also used. Chemical compositions were determined by wet chemical analysis and electron microprobe techniques. Secondary minerals in basalt groundmass were studied in the $\langle 1 \mu \mathrm{m}$ and 1 to $10 \mu \mathrm{m}$ fractions.

\section{SECONDARY MINERALS IN BASALT GROUNDMASS}

Trioctahedral smectites are the principal secondary minerals in the basalt groundmass. Talc, which was found in Sample 504B-5-2, 142-146 cm, seems to have come from a thin veinlet. Minor chlorite was identified in the groundmass of basalt from Hole 501 only (Table 1).

Smectites, which formed by the alteration of interstitial glass and olivine, were identified by X-ray diffraction analysis in all samples studied. The basal reflection (001) varied from 13.6 to $15.2 \AA$, and the $b$-parameter varied from 9.18 to $9.21 \AA$ (Sample 504B-7-2, 64-68 $\mathrm{cm}, 9.19 \AA$; $504 \mathrm{~B}-24-1,125-129 \mathrm{~cm}, 9.18$ and $9.21 \AA$; 504B-70-1, 17-20 cm, $9.21 \AA$ ). As shown in Figure 1, the $b$-parameter suggests that the smectites are triocta-

\footnotetext{
${ }^{1}$ Cann, J. R., Langseth, M. G., Honnorez, J., Von Herzen, R. P., White, S. M., et al., Init. Repts. DSDP, 69: Washington (U.S. Govt. Printing Office).
}

Table 1. Occurrence of secondary minerals in basalt groundmass from Costa Rica Rift, Holes 501 and 504B, Legs 68, 69, and 70.

\begin{tabular}{|c|c|c|c|c|c|c|c|}
\hline \multirow{2}{*}{$\begin{array}{c}\text { Sample } \\
\text { (interval in } \mathrm{cm} \text { ) }\end{array}$} & \multirow{2}{*}{$\begin{array}{l}\text { Sub-bottom } \\
\text { Depth (m) }\end{array}$} & \multicolumn{3}{|c|}{ Saponite } & \multicolumn{3}{|c|}{ Chlorite } \\
\hline & & $<1 \mu \mathrm{m}$ & 1 to $10 \mu \mathrm{m}$ & Bulk & $<1 \mu \mathrm{m}$ & 1 to $10 \mu \mathrm{m}$ & Bulk \\
\hline $501-10-2,10-12$ & 265.70 & $\mathrm{~T}$ & $T$ & & & & \\
\hline $12-1,71-73$ & 273.81 & $r$ & 2 & & & & \\
\hline $14-4,69-71$ & 288.29 & 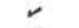 & $\mathrm{T}$ & & & & \\
\hline $15-1,109-111$ & 293.19 & r & - & & & $\mathbf{T}$ & \\
\hline $15-3,134-136$ & 296.44 & r & $\mathrm{T}$ & & & & \\
\hline $17-3,18-20$ & 305.28 & r & $\mathrm{T}$ & & & & \\
\hline $20-1,39-41$ & 328.49 & $r$ & - & & $\mathbf{T}$ & $\mathrm{T}$ & \\
\hline $504 \mathrm{~B}-3-1,96-99$ & 278.96 & r & $r$ & & & & \\
\hline $4-1,62-64$ & 280.64 & $r$ & r & & & & \\
\hline $4-3,108-111$ & 284.08 & 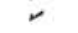 & r & & & & \\
\hline $4-4,42-45$ & 284.92 & & & $\mathrm{~T}$ & & & \\
\hline $4-5,87-90$ & 286.87 & & & $T$ & & & \\
\hline $\begin{array}{l}5-2,142-146^{\mathrm{a}} \\
6-1,65-69\end{array}$ & $\begin{array}{l}290.92 \\
299.15\end{array}$ & $\frac{T}{r}$ & $\bar{r}$ & & & & \\
\hline $\begin{array}{l}6-1,65-69 \\
6-3,3-7\end{array}$ & 301.53 & 2 & 2 & T & & & \\
\hline $7-2,64-68$ & 309.64 & $r$ & r & & & & \\
\hline $8-3,61-66$ & 320.11 & r & r & & & & \\
\hline $9-1,142-147$ & 326.92 & r & r & & & & \\
\hline $10-3,17-20$ & 337.67 & r & r & & & & \\
\hline $12-1,39-43$ & 361.89 & r & r & & & & \\
\hline $13-4,40-44$ & 366.40 & & & $\mathbf{T}$ & & & \\
\hline $15-1,24-28$ & 375.24 & r & r & & & & \\
\hline $16-1,45-49$ & 384.45 & & & $\mathrm{~T}$ & & & \\
\hline $\begin{array}{l}16-4,22-26 \\
17-1,30-34\end{array}$ & $\begin{array}{l}385.72 \\
393.30\end{array}$ & $r$ & r & $\mathrm{T}$ & & & \\
\hline $18-1,45-49$ & 398.45 & & & 2 & & & \\
\hline $19-1,84-87$ & 403.84 & r & $r$ & & & & \\
\hline $20-1,110-113$ & 413.10 & & & $\mathrm{~T}$ & & & \\
\hline $21-2,126-130$ & 423.76 & & & $T$ & & & \\
\hline $21-5,63-66$ & 427.63 & & & $\mathbf{T}$ & & & \\
\hline $22-1,106-109$ & 431.06 & r & r & & & & \\
\hline $24-1,125-128$ & 449.25 & r & r & 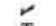 & & & \\
\hline $26-1,15-18$ & 463.15 & & & $\mathrm{~T}$ & & & \\
\hline $27-2,55-58$ & 468.05 & r & r & & & & \\
\hline $28-3,69-73$ & 478.68 & & & $r$ & & & \\
\hline $32-2,137-140$ & 510.37 & $r$ & r & & & & \\
\hline $33-1,86-88$ & 517.36 & $r$ & $r$ & & & & \\
\hline $34-1,140-142$ & 526.90 & r & - & & & & \\
\hline $35-1,70-72$ & 535.30 & $\sim$ & $\Sigma$ & & & & \\
\hline $\begin{array}{l}37-1,15-20 \\
39-2,97-102\end{array}$ & $\begin{array}{l}552.65 \\
572.97\end{array}$ & $\Sigma$ & $\Sigma$ & & & & \\
\hline $47-2,130-140$ & 640.80 & r & r & & & & \\
\hline $49-1,122-126$ & 657.22 & r & r & & & & \\
\hline $61-2,145-149$ & 753.40 & - & r & & & & \\
\hline $67-1,45-49$ & 800.45 & r & r & & & & \\
\hline $70-1,17-20$ & 827.17 & r & r & & & & \\
\hline
\end{tabular}

Note: $\mathrm{T}$ denotes trace.

a Trace of talc(?). 


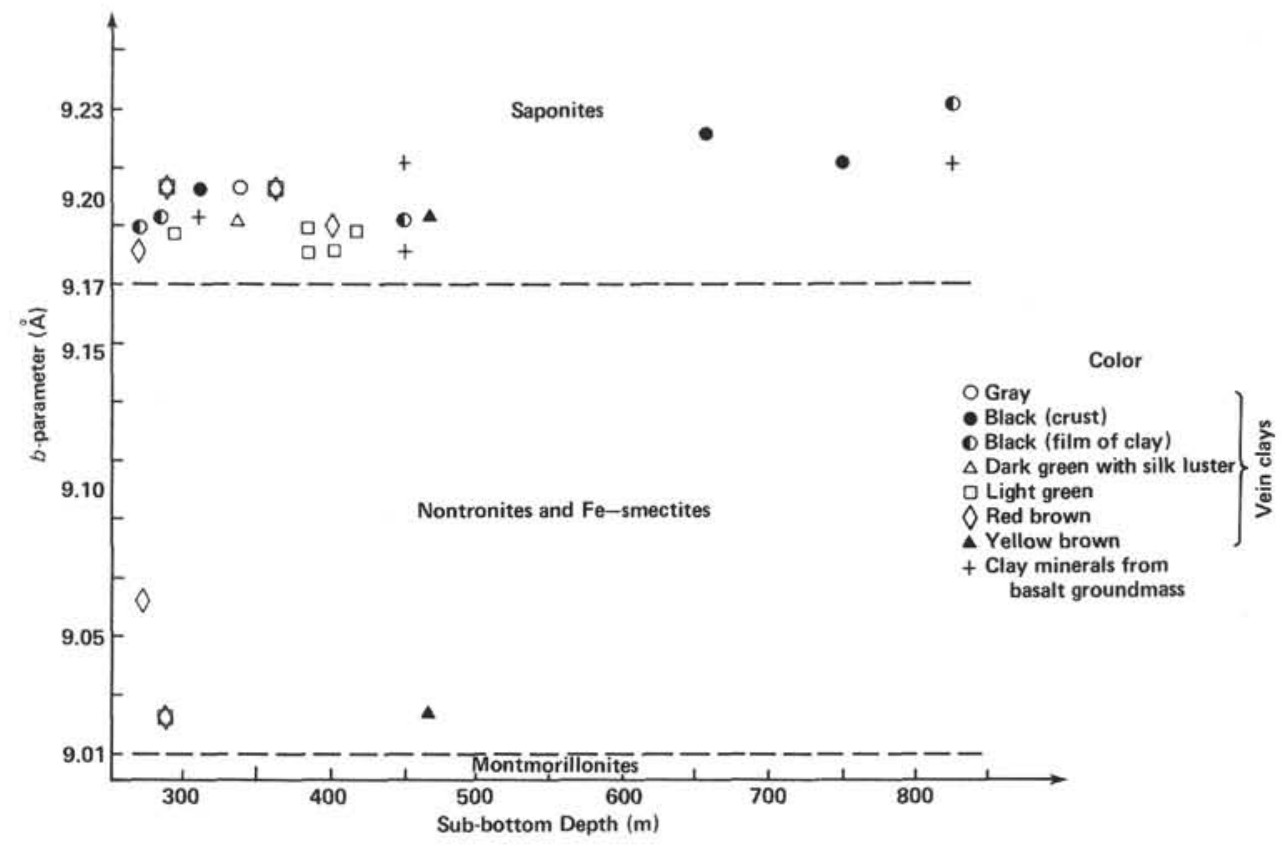

Figure 1. $b$-parameter of clays from veins and basalt groundmass, Hole 504B, Costa Rica Rift, Legs 69 and 70 , plotted versus depth below the seafloor.

hedral. The smectites consist of isometric fragments of different size and thickness (Plate 1, Fig. 1) or (rarely) elongated lamellae and needles.

Chemical analysis of the $<1 \mu \mathrm{m}$ fraction derived from basalt shows that the smectite is a low- $\mathrm{K} \mathrm{Fe}-\mathrm{Mg}$-saponite (Table 2). The composition of the groundmass saponite changes slightly through the basalt section. From about 470 meters sub-bottom (Sample 504B-27-2, 55-58 cm) downward, the smectite decreases in $\mathrm{MgO}$ and increases in $\mathrm{CaO}$ and $\mathrm{Na}_{2} \mathrm{O}$ content. The very lowest sample (Sample 504B-70-1) has high levels of $\mathrm{Fe}_{2} \mathrm{O}_{3}$ and $\mathrm{Fe}_{2} \mathrm{O}_{3}+\mathrm{FeO}$ and the lowest $\mathrm{K}_{2} \mathrm{O}$ content.

Chemical analysis shows that the $<1 \mu \mathrm{m}$ fraction does not consist entirely of saponite; this fraction also contains plagioclase and volcanic glass.

\section{MINERALS IN VEINS AND VESICLES}

The following minerals were identified in basalt veins and vesicles: saponite, $\mathrm{Fe}$-smectite, chlorite, talc, mixedlayer minerals, hematite, pyrite, phillipsite, foujasite, analcime, natrolite, thomsonite, gyrolite, aragonite, calcite, anhydrite, Fe-hydrosilicate, chalcocite, okenite, apophyllite, actinolite, cristobalite, quartz, bismutite(?), and magnesite (Table 3). A mineral rich in Mn and minerals with strong reflections at $12.9 \AA$ and $3.20 \AA$ could not be identified.

\section{Clay Minerals}

Clays from the veins and vesicles are trioctahedral smectites (saponites) of diverse color-black and dark green, gray, dark green with a silk luster, light green, yellow brown, and red brown (Fig. 1). The $b$-parameter of these clays ranges from 9.18 to $9.23 \AA$. Minor dioctahedral smectite $(b=9.02,9.04$, and $9.06 \AA$ ) was found in the light green, yellow brown, and red brown clays.

The black and dark green clays in the veins are low-K $\mathrm{Fe}-\mathrm{Mg}$-saponites (Table 4). The $\mathrm{MgO}$ content of these varieties ranges from 12 to $20 \%$, the $\mathrm{Fe}_{2} \mathrm{O}_{3}+\mathrm{FeO}$ content from 10 to $17 \%$. Most particles are isometric in form, but some lath-shaped fragments were identified in

Table 2. Wet chemical composition (wt.\%) of saponites from the $<1 \mu \mathrm{m}$ fraction of basalt from Costa Rica Rift, Legs 69 and 70.

\begin{tabular}{|c|c|c|c|c|c|c|c|c|c|c|}
\hline \multirow[b]{2}{*}{ Component } & \multicolumn{10}{|c|}{ Sample (interval in cm) } \\
\hline & $\begin{array}{c}504 \mathrm{~B}-4-1 \\
(62-64)\end{array}$ & $\begin{array}{c}504 \mathrm{~B}-7-2 \\
(64-68)\end{array}$ & $\begin{array}{c}504 \mathrm{~B}-10-3 \\
(17-20)\end{array}$ & $\begin{array}{c}504 \mathrm{~B}-15-1 \\
(24-28)\end{array}$ & $\begin{array}{l}504 \mathrm{~B}-24-1 \\
(125-128)\end{array}$ & $\begin{array}{c}504 B-27-2 \\
(55-58)\end{array}$ & $\begin{array}{l}504 \mathrm{~B}-35-1 \\
(110-112)\end{array}$ & $\begin{array}{l}504 \mathrm{~B}-49-1 \\
(122-126)\end{array}$ & $\begin{array}{l}504 \mathrm{~B}-61-2 \\
(145-149)\end{array}$ & $\begin{array}{c}504 \mathrm{~B}-70-1 \\
(17-20)\end{array}$ \\
\hline $\mathrm{SiO}_{2}$ & 43.12 & 47.50 & 47.46 & 47.72 & 45.86 & 48.14 & 44.53 & 45.05 & 46.26 & 45.58 \\
\hline $\mathrm{TiO}_{2}^{2}$ & 0.83 & 0.08 & 0.78 & 0.36 & 0.69 & 0.35 & 0.77 & 0.88 & 0.71 & 1.00 \\
\hline $\mathrm{Al}_{2} \mathrm{O}_{3}$ & 13.99 & 7.30 & 10.54 & 9.06 & 11.00 & 12.37 & 15.05 & 13.53 & 11.90 & 10.04 \\
\hline $\mathrm{Fe}_{2} \mathrm{O}_{3}$ & 8.95 & 10.00 & 8.82 & 10.56 & 9.28 & 6.67 & 9.84 & 10.93 & 8.22 & 13.15 \\
\hline $\mathrm{FeO}$ & 1.96 & 1.31 & 3.11 & 1.31 & 1.96 & 2.22 & 1.44 & 1.18 & 1.96 & 1.05 \\
\hline $\mathrm{MnO}$ & 0.15 & 0.08 & 0.12 & 0.08 & 0.18 & 0.13 & 0.12 & 0.10 & 0.11 & 0.09 \\
\hline $\mathrm{MgO}$ & 11.86 & 19.50 & 15.45 & 16.83 & 16.36 & 13.92 & 8.91 & 11.14 & 12.31 & 12.10 \\
\hline $\mathrm{CaO}$ & 1.76 & 0.92 & 3.08 & 2.02 & 4.71 & 5.07 & 9.03 & 4.80 & 6.64 & 3.54 \\
\hline $\mathrm{Na}_{2} \mathrm{O}$ & 0.27 & 0.26 & 0.68 & 0.56 & 0.65 & 1.13 & 1.14 & 0.59 & 0.96 & 0.87 \\
\hline $\mathrm{K}_{2} \mathrm{O}$ & 0.17 & 0.09 & 0.12 & 0.07 & 0.19 & 0.22 & 0.19 & 0.12 & 0.07 & 0.04 \\
\hline L.O.1. ${ }^{\mathrm{a}}$ & & 13.29 & 9.68 & 11.68 & & 9.38 & 8.83 & & 10.46 & 12.91 \\
\hline Total & & 100.33 & 99.84 & 100.25 & & 99.80 & 99.85 & & 99.60 & 100.37 \\
\hline
\end{tabular}


Table 3. Summary of secondary minerals identified in veins and vesicles of basalts from the Costa Rica Rift, Legs 68, 69, and 70.

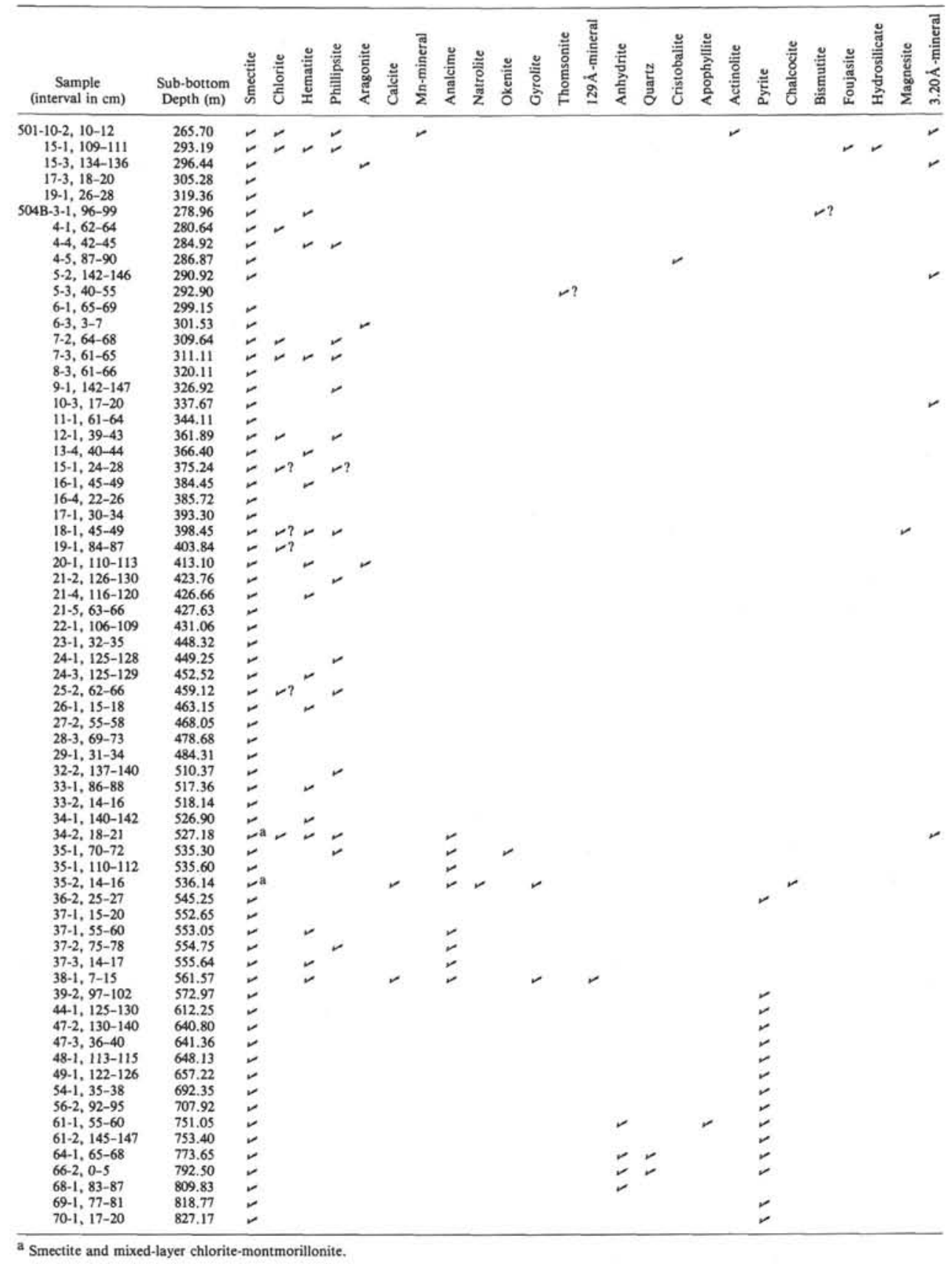

Sample 504B-29-1, 31-34 cm. The structure of smectite in black clay is shown in Tables 2 and 4.

Analyses were made of green saponite clays that occur as globules in veins in Samples 501-15-1, 109-111 cm and 504B-16-1, 45-49 cm. The clays are saponites with a content of $\mathrm{MgO}$ up to $22 \%$ and a maximum $\mathrm{K}_{2} \mathrm{O}$ content of $0.33 \%$ (Table 5 ). Black clay located along the walls of a vein in Sample 501-15-1, 109-111 cm has higher iron and alumina contents, lower magnesium content, and significantly higher $\mathrm{K}_{2} \mathrm{O}$ content $(2.4 \%)$ (Table 5$)$.

Green clays in veins from the zeolite zone (Samples 504B-34-2, 18-21 cm; 504B-35-2, 14-16 cm; and 504B$38-1,7-15 \mathrm{~cm}$ ) were also studied. In Sample 504B-34-2,
$18-21 \mathrm{~cm}$ a brecciated glassy crust is composed of fine blocks of glass altered to smectite. These blocks consist of dark green saponite with $18 \% \mathrm{MgO}$ and $0.63 \% \mathrm{~K}_{2} \mathrm{O}$ (Table 5). The centers of the blocks consist of lighter green $\mathrm{Fe}-\mathrm{Mg}$-saponite with $4.17 \% \mathrm{~K}_{2} \mathrm{O}$. In the same sample there is a white smectite vein at the glassy crust/ basalt contact. Its chemical composition is as follows: $\mathrm{SiO}_{2}, 50.13 ; \mathrm{TiO}_{2}, 0.01 ; \mathrm{Al}_{2} \mathrm{O}_{3}, 8.93 ; \mathrm{FeO}, 6.26$ (total $\mathrm{Fe}$ as $\mathrm{FeO}$ ); $\mathrm{MnO}, 0.17 ; \mathrm{MgO}, 19.83 ; \mathrm{CaO}, 1.25 ; \mathrm{Na}_{2} \mathrm{O}$, $0.94 ; \mathrm{K}_{2} \mathrm{O}, 1.12 \%$; total, $88.64 \%$.

In Sample 504B-35-2, 14-16 cm, first green and then dark green ( $\mathrm{Fe}-\mathrm{MgO}$-saponite) clays occur as one proceeds from the central part of a vein (which consists of 
Table 4. Chemical composition (wt.\%) of saponites from clay veins of basalts from the Costa Rica Rift, Legs 69 and 70.

\begin{tabular}{|c|c|c|c|c|c|c|c|c|}
\hline \multirow[b]{4}{*}{ Component } & \multicolumn{8}{|c|}{ Sample (interval in cm) } \\
\hline & $\begin{array}{r}504 \mathrm{~B}-5-2 \\
(142-146) \\
\end{array}$ & $\begin{array}{c}504 \mathrm{~B}-10-3 \\
(17-20)\end{array}$ & $\begin{array}{c}504 \mathrm{~B}-16-1 \\
(45-49)\end{array}$ & $\begin{array}{l}504 \mathrm{~B}-32-2 \\
(137-140)\end{array}$ & $\begin{array}{l}504 \mathrm{~B}-32-2 \\
(137-140)\end{array}$ & $\begin{array}{l}504 \mathrm{~B}-49-1 \\
(122-126)\end{array}$ & $\begin{array}{c}504 \mathrm{~B}-61-1 \\
(55-60)\end{array}$ & $\begin{array}{c}504 \mathrm{~B}-70-1 \\
(17-20)\end{array}$ \\
\hline & \multicolumn{8}{|c|}{ Color of Clay } \\
\hline & Light Green & Gray & Light Green & Black & Black & Black & Dark Green & Black \\
\hline $\mathrm{SiO}_{2}$ & 45.52 & 47.60 & & & 39.47 & & 44.97 & \\
\hline $\mathrm{TiO}_{2}$ & 0.22 & 0.13 & & & 0.41 & & 0.08 & \\
\hline $\mathrm{Al}_{2} \mathrm{O}_{3}$ & 6.20 & 6.20 & & 6.80 & 9.93 & 14.25 & 5.80 & 13.10 \\
\hline $\mathrm{Fe}_{2} \mathrm{O}_{3}$ & 4.95 & 4.55 & & 14.17 & 11.60 & 5.93 & 3.20 & 9.73 \\
\hline $\mathrm{FeO}$ & 7.20 & 7.03 & & 2.94 & 5.89 & 4.91 & 6.05 & 2.78 \\
\hline MnO & 0.13 & 0.09 & & & 0.13 & & 0.07 & \\
\hline $\mathrm{MgO}$ & 19.28 & 21.23 & & & 12.56 & & 20.35 & \\
\hline $\mathrm{CaO}$ & 1.79 & 0.75 & & & 2.25 & & 2.13 & \\
\hline $\mathrm{Na}_{2} \mathrm{O}$ & & 1.71 & 1.49 & 1.25 & 1.32 & 1.12 & 0.95 & 1.71 \\
\hline $\mathrm{K}_{2} \mathrm{O}$ & & 0.20 & 0.33 & 0.62 & 0.40 & 0.19 & 0.02 & 0.03 \\
\hline L.O.I. ${ }^{a}$ & & 10.18 & & & 15.69 & & 11.11 & \\
\hline Total & & 99.67 & & & 99.65 & & 99.74 & \\
\hline
\end{tabular}

Table 5. Chemical composition of clay minerals from veins of basalt, Costa Rica Rift, Legs 68,69 , and 70 .

\begin{tabular}{|c|c|c|c|c|c|c|c|c|c|}
\hline \multirow[b]{4}{*}{ Component } & \multicolumn{9}{|c|}{ Sample (interval in $\mathrm{cm}$ ) } \\
\hline & $\begin{array}{c}501-15-1 \\
(109-111)\end{array}$ & $\begin{array}{c}501-15-1 \\
(109-111)\end{array}$ & $\begin{array}{c}504 \mathrm{~B}-16-1 \\
(45-49)\end{array}$ & $\begin{array}{c}504 \mathrm{~B}-16-1 \\
(45-49)\end{array}$ & $\begin{array}{c}504 \mathrm{~B}-34-2 \\
(18-21)\end{array}$ & $\begin{array}{c}504 \mathrm{~B}-34-2 \\
(18-21)\end{array}$ & $\begin{array}{c}504 \mathrm{~B}-35-2 \\
(14-16)\end{array}$ & $\begin{array}{c}\text { 504B-35-2 } \\
(14-16)\end{array}$ & $\begin{array}{c}504 \mathrm{~B}-38-1 \\
(7-15)\end{array}$ \\
\hline & \multicolumn{9}{|c|}{ Color of Clay } \\
\hline & (a) & (b) & (c) & (d) & (e) & (f) & (f) & (g) & (g) \\
\hline $\mathrm{SiO}_{2}$ & 44.66 & 43.43 & 52.72 & 49.04 & 53.35 & 46.44 & 42.98 & 46.00 & 43.12 \\
\hline $\mathrm{TiO}_{2}$ & 0.02 & 0.78 & 0.01 & 0.03 & 0.49 & 0.73 & 0.02 & 1.54 & 0.16 \\
\hline $\mathrm{Al}_{2} \mathrm{Q}_{3}$ & 5.34 & 13.56 & 4.36 & 4.85 & 11.03 & 13.20 & 7.02 & 11.76 & 11.90 \\
\hline $\mathrm{FeO}^{3}$ & 9.13 & 15.77 & 9.19 & 10.47 & 14.09 & 11.49 & 12.52 & 16.65 & 11.51 \\
\hline $\mathrm{MnO}$ & 0.06 & 0.18 & 0.02 & 0.03 & 0.19 & 0.41 & 0.15 & 0.16 & 0.25 \\
\hline $\mathrm{MgO}$ & 22.03 & 10.19 & 19.03 & 18.64 & 10.55 & $\begin{array}{l}0.41 \\
18.48\end{array}$ & 15.10 & 13.12 & 13.51 \\
\hline $\mathrm{CaO}$ & 0.64 & 0.67 & 0.34 & 0.52 & 1.73 & 1.97 & 0.55 & 0.79 & 2.48 \\
\hline $\mathrm{Na}_{2} \mathrm{O}$ & 1.20 & 0.22 & 1.95 & 2.36 & 0.18 & 0.16 & 1.46 & 0.42 & 0.40 \\
\hline $\mathrm{K}_{2} \mathrm{O}$ & 0.33 & 2.46 & 0.11 & 0.03 & 4.17 & 0.63 & 4.48 & 1.91 & 0.60 \\
\hline Total & 83.41 & 87.24 & 87.72 & 86.02 & 95.77 & 93.52 & 84.41 & 92.35 & 83.95 \\
\hline \multicolumn{10}{|c|}{$\begin{array}{l}\text { a Green (globules from center of vein). } \\
\mathrm{b} \text { Black (basaltward from center of vein). } \\
\text { c Light green (rim of green globule). } \\
\mathrm{d} \text { Green (center of globule). } \\
\mathrm{e} \text { Green into dark green. } \\
\text { f Dark green. } \\
\mathrm{g} \text { Green. } \\
\text { h Total Fe as FeO. }\end{array}$} \\
\hline
\end{tabular}

natrolite and calcite) toward basalt. Of the two clays, the dark green clay is richer in $\mathrm{K}_{2} \mathrm{O}(4.48 \%)$ and $\mathrm{Na}_{2} \mathrm{O}$ $(1.46 \%)$ (Table 5). The green clay has higher alumina and iron contents, slightly lower $\mathrm{MgO}$ content, and lower $\mathrm{K}_{2} \mathrm{O}(1.91 \%)$ and $\mathrm{Na}_{2} \mathrm{O}(0.42 \%)$ content.

In Sample 504B-38-1, 7-15 cm, green clay occurs in association with analcime, calcite, and gyrolite. It consists of $\mathrm{Fe}-\mathrm{Mg}$-saponite with a $\mathrm{K}_{2} \mathrm{O}$ content of $0.60 \%$ (Table 5).

The gray clay is another $\mathrm{Fe}-\mathrm{Mg}$-saponite with low $\mathrm{K}_{2} \mathrm{O}$ content $(0.20 \%)$. $\mathrm{MgO}$ content is $21.23 \%$, and $\mathrm{Fe}_{2} \mathrm{O}_{3}$ content is $4.55 \%$ (Table 4). Particles are lath shaped or ribbonlike (Plate 1, Fig. 2). Under the scanning electron microscope, the gray clay shows a rosette texture (Plate 2, Figs. 1 and 2). Traces of chlorite were also identified in this clay (Samples 504B-15-1, 19-1 cm and $21-2 \mathrm{~cm}$ ).

The dark green clay with a silk luster is also saponite with lath-shaped particles. Its natural texture is shown in Plate 2, Figure 3.

The light green clay consists of saponite, and its chemical composition is close to that of the gray clay (Table 4). Infrared patterns of light green clay show only saponite reflections. Particles are lath shaped (Plate 1, Fig. 3).
The yellow brown clay is similar to the light green clay.

The red brown clay consists of saponite and finely dispersed hematite, with traces of dioctahedral Fe-smectite ( $b$-parameter, up to $9.06 \AA$ ). The clay particles are isometric in shape (Plate 1, Fig. 4).

A comparison of the chemical composition of the clay minerals in the veins and basalt groundmass shows that the clay minerals in the veins are usually higher in $\mathrm{MgO}$, lower in $\mathrm{Fe}_{2} \mathrm{O}_{3}$ and $\mathrm{Al}_{2} \mathrm{O}_{3}$, and sometimes higher in $\mathrm{K}_{2} \mathrm{O}$ (Samples 504B-5-2, 504B-10-3, 504B-29-1, and $504 \mathrm{~B}-61-1)$. Light green clay in a vein in the oxidized zone (Sample 504B-5-2) is not distinguished by its chemical composition.

\section{Other Minerals}

All the secondary nonclay minerals that were found are enumerated in the preceding material. They were identified by X-ray diffraction analysis (Joint Committee on Powder Diffraction Standards, 1974).

The unknown mineral rich in Mn in Sample 501-10-2, $10-12 \mathrm{~cm}$ was also analyzed by microprobe techniques (Table 6). The central part of the mineral contains $19.84 \% \mathrm{MnO}$ (P-trace) and $2.53 \% \mathrm{MgO}$. Narrow zones analogous in composition to the central part of the min- 
Table 6. Chemical composition (wt.\%) of a Mn-rich mineral from basalt of Costa Rica Rift, Sample 501-10-2, 10-12 cm, Leg 68.

\begin{tabular}{lrr}
\hline Component & $\begin{array}{c}\text { Center } \\
\text { of } \\
\text { Mineral }\end{array}$ & $\begin{array}{c}\text { Rim } \\
\text { of } \\
\text { Mineral }\end{array}$ \\
\hline $\mathrm{SiO}_{2}$ & 33.29 & 41.02 \\
$\mathrm{TiO}_{2}$ & 0.03 & 0.01 \\
$\mathrm{Al}_{2} \mathrm{O}_{3}$ & 6.96 & 12.16 \\
$\mathrm{FeO}^{\mathrm{a}}$ & 0.09 & 2.85 \\
$\mathrm{MnO}$ & 19.84 & 4.19 \\
$\mathrm{MgO}$ & 2.53 & 23.15 \\
$\mathrm{CaO}$ & 19.06 & 2.73 \\
$\mathrm{Na} 2 \mathrm{O}$ & 0.02 & 0.83 \\
$\mathrm{~K}_{2} \mathrm{O}$ & 0.01 & 0.11 \\
Total & 81.84 & 87.05 \\
\hline
\end{tabular}

a Total $\mathrm{Fe}$ as $\mathrm{FeO}$.

eral alternate with zones containing about $4 \% \mathrm{MnO}$ and up to about $23 \% \mathrm{MgO}$, with higher $\mathrm{Al}_{2} \mathrm{O}_{3}, \mathrm{SiO}_{2}, \mathrm{FeO}$, $\mathrm{Na}_{2} \mathrm{O}$, and $\mathrm{K}_{2} \mathrm{O}$ contents and much lower $\mathrm{CaO}$ contents (to $2.73 \%$ ). We failed to identify the Mn-rich mineral.

Chalcocite was identified in Sample 504B-35-2, 14$16 \mathrm{~cm}$ from microprobe data. Weak 3.76, 2.94, and 2.139 $\AA \mathrm{X}$-ray reflections in clay from Sample 504B-3-1, 94$96 \mathrm{~cm}$ were attributed to bismutite.

The results of microprobe analyses of analcime and natrolite are given in Table 7. Natrolite has a high $\mathrm{K}_{2} \mathrm{O}$ content (up to 5\%). Part of a vein in another sample is milk white, and the chemical composition of this part of the vein, which according to X-ray diffraction analysis consists of analcime $(5.57,3.42$, and $2.92 \AA)$, calcite $(3.03 \AA)$, and an unidentified mineral with a strong reflection at $12.9 \AA$, is shown in Table 8 . The $\mathrm{CaO}$ content of this part of the vein is high (up to $24.49 \%$ ). It is possible that the $3.03 \AA$ reflection attributed to calcite actually belongs to the mineral with the strong reflection at $12.9 \AA$. This mineral appears to be in an isomorphous

Table 7. Chemical composition (wt. \%) of vein minerals from basalts of Costa Rica Rift, Legs 68, 69, and 70.

\begin{tabular}{lcccc}
\hline & \multicolumn{4}{c}{ Sample (interval in cm) } \\
\cline { 2 - 5 } & $\begin{array}{c}504 \mathrm{~B}-38-1 \\
(7-15)\end{array}$ & $\begin{array}{c}505 \mathrm{~B}-35-2 \\
(14-16)\end{array}$ & $\begin{array}{c}501-15-1 \\
(109-111)\end{array}$ & $\begin{array}{c}501-15-1 \\
(109-111)\end{array}$ \\
\cline { 2 - 5 } Component & \multicolumn{4}{c}{ Mineral } \\
\cline { 2 - 5 } & Analcime & Natrolite & Foujasite & Phillipsite \\
\hline $\mathrm{SiO}_{2}$ & 57.39 & 53.39 & 51.63 & 52.10 \\
$\mathrm{TiO}_{2}$ & 0.02 & 0.02 & 0.24 & 0.26 \\
$\mathrm{Al}_{2} \mathrm{O}_{3}$ & 21.95 & 16.36 & 15.97 & 18.95 \\
$\mathrm{FeO}^{a}$ & - & 0.23 & 0.10 & 0.06 \\
$\mathrm{MnO}$ & 0.01 & - & 0.02 & - \\
$\mathrm{MgO}$ & - & - & 0.18 & - \\
$\mathrm{CaO}$ & 0.02 & 0.34 & 3.07 & 0.98 \\
$\mathrm{Na} 2 \mathrm{O}$ & 15.23 & 7.61 & 6.84 & 8.70 \\
$\mathrm{~K}_{2} \mathrm{O}$ & 0.01 & 5.08 & 0.07 & 4.70 \\
$\mathrm{Total}$ & 94.65 & 83.02 & 78.12 & 85.76 \\
\hline
\end{tabular}

Note: Dash denotes that element was not found.

a Total $\mathrm{Fe}$ as $\mathrm{FeO}$.
Table 8. Chemical composition (wt.\%) of vein minerals from basalts of Costa Rica Rift, Leg 70.

\begin{tabular}{lccc}
\hline & \multicolumn{3}{c}{ Sample (interval in cm) } \\
\cline { 2 - 4 } & $\begin{array}{c}504 \mathrm{~B}-38-1 \\
(7-15)\end{array}$ & $\begin{array}{c}504 \mathrm{~B}-38-1 \\
(7-15)\end{array}$ & $\begin{array}{c}504 \mathrm{~B}-5-3 \\
\text { (Piece 391, 40-55) }\end{array}$ \\
\cline { 2 - 4 } Component & \multicolumn{3}{c}{ Color and/or Mineral } \\
\cline { 2 - 4 } & (a) & (b) & (c) \\
\hline $\mathrm{SiO}_{2}$ & 49.57 & 53.15 & 36.55 \\
$\mathrm{TiO}_{2}$ & 0.01 & 0.01 & 32.89 \\
$\mathrm{Al}_{2} \mathrm{O}_{3}$ & 7.58 & 1.77 & 0.04 \\
$\mathrm{FeO}$ & 0.05 & 0.01 & - \\
$\mathrm{MnO}$ & - & 0.02 & - \\
$\mathrm{MgO}$ & - & - & 13.69 \\
$\mathrm{CaO}$ & 24.49 & 32.94 & 3.64 \\
$\mathrm{Na} 2 \mathrm{O}$ & 1.94 & 0.10 & - \\
$\mathrm{K}_{2} \mathrm{O}$ & 0.07 & 0.03 & 86.81 \\
$\mathrm{Total}$ & 83.72 & 88.02 & \\
\hline
\end{tabular}

Note: Dash denotes that element was not found.

a Milk white (analcime, $12.9 \AA$-mineral, and calcite).

b Gray.

c Thomsonite (analyzed by N. N. Pertsev).

d Total $\mathrm{Fe}$ as $\mathrm{FeO}$.

mixture with analcime. The chemical composition of the gray part of the same vein is also shown in Table 8.

Okenite was identified from its $19.6 \AA$ reflection in material from an analcime-filled vein in Sample 504B$35-1,70-72 \mathrm{~cm}$.

An unidentified mineral with a strong reflection at $3.20 \AA$ (possibly fairchildite) was found in Samples 50110-2, 501-15-3, 504B-5-2, 504B-10-3, and 504B-34-2.

Vein foujasite (identified by a strong reflection at $14.25 \AA$ ) was found in Sample 501-15-1, 109-111 cm together with phillipsite. The chemical composition of foujasite is shown together with that of phillipsite in Table 7. Fe-hydrosilicate (Table 9) was detected in the same sample by microprobe analysis.

A red ferruginous film found in Sample 504B-18-1, $45-49 \mathrm{~cm}$ was studied by $\mathrm{X}$ ray. Hematite was identified by its $3.65,2.70,2.50,2.20,1.83$, and $1.68 \AA$ reflec-

Table 9. Chemical composition of vein iron mineral from basalt of Costa Rica Rift, Sample 501-15-1, 109-111 cm, Leg 68.

\begin{tabular}{lrr}
\hline Component & & \\
\hline $\mathrm{SiO}_{2}$ & 10.93 & 7.36 \\
$\mathrm{TiO}_{2}$ & - & 0.05 \\
$\mathrm{Al}_{2} \mathrm{O}_{3}$ & 3.06 & 2.49 \\
$\mathrm{FeO}^{\mathrm{a}}$ & 63.97 & 62.43 \\
$\mathrm{MnO}$ & 0.39 & 0.45 \\
$\mathrm{MgO}$ & 2.81 & 2.23 \\
$\mathrm{CaO}$ & 0.43 & 0.30 \\
$\mathrm{Na}_{2} \mathrm{O}$ & 0.14 & 0.14 \\
$\mathrm{~K}_{2} \mathrm{O}$ & 0.18 & 0.03 \\
Total & 81.92 & 75.48 \\
\hline
\end{tabular}

Note: Dash denotes that element was not found.

a Total $\mathrm{Fe}$ as $\mathrm{FeO}$. 
tions. Reflections at $2.77,2.50,2.14$, and $1.70 \AA$ were attributed to magnesite.

Thomsonite, which was identified by N. N. Pertsev on the basis of its chemical composition (Table 8), was not identified by X-ray diffraction analysis, probably because it is present in very small amounts.

An aragonite vein and pyrite are shown in Plate 3, Figures 1 to 4 . A sphere of unknown composition occurs on the pyrite in Sample 504B-61-1, 55-60 cm (Plate 3 , Figs. 5 and 6 ). We have found analogous shapes before (during a study of gold morphology). Excellent trioctahedral $\mathrm{Fe}-\mathrm{Mg}$-chlorite was revealed together with vein smectite and analcime in Sample 504B-34-2, 18-21 $\mathrm{cm}$.

\section{MINERAL ASSOCIATIONS}

Vein minerals identified in the Costa Rica Rift basalts occur in the following principal associations: black clay + hematite \pm light green clay and phillipsite; black clay + pyrite; black clay + gray clay \pm phillipsite; black clay + aragonite; black clay + analcime + other $\mathrm{Ca}$-, $\mathrm{Na}-$, and K-minerals; black clay + anhydrite + quartz \pm apophyllite; and green clay in pores.

Black clay is widespread, present in thin veins through the whole basalt section. Thick layers of black clay were found mainly in brecciated glassy crusts. Hematite and pyrite divide the basalt into two significant parts: an interval with hematite from 278 to 570 meters sub-bottom and an interval with pyrite from 570 to 827 meters subbottom. Light green clay, which occurs as thin, 1-mmthick layers that cover the black clay, is present mainly to the depth of 570 meters sub-bottom.

The vein mineral assemblages can be used to divide the interval from 278 to 570 meters sub-bottom into three parts in turn: from 278 to $\mathbf{4 2 7}$ meters sub-bottom, 427 to 527 meters sub-bottom, and 527 to 570 meters sub-bottom.

Gray clay occurs at depths up to 427 meters sub-bottom. It exists as shapeless lumps and clearly outlined fragments and occurs mainly in brecciated glassy crusts. It also occurs in veins up to $1 \mathrm{~cm}$ wide with black clay, dark green clay with a silk luster, and phillipsite (Plate 2, Figs. 4 and 5). The contact between gray and black clays is distinct and metasomatic. Bismutite(?), actinolite, and chlorite were identified in the gray clay. In the same part of the basalt section (to a depth of 427 meters sub-bottom) black clay lines veins that are filled with aragonite. In this part of the section talc, thomsonite, cristobalite, a mineral rich in $\mathrm{Mn}$, foujasite, $\mathrm{Fe}$-hydrosilicate, magnesite, and a mineral with a reflection at 3.20 $\AA$ were also detected.

In the interval from 427 to 527 meters sub-bottom hematite and phillipsite were identified in veins lined with black clay.

In the interval from 527 to 570 meters sub-bottom the black clay lines veins that are filled mainly with analcime. Natrolite, okenite, gyrolite, calcite, phillipsite, chalcocite, chlorite, and an unidentified $12.9 \AA$ mineral were also found in association with the analcime. These veins occur mainly in the glassy crusts and brecciated glass.
Pyrite is a common mineral in the interval from $\mathbf{5 7 0}$ to 827 meters sub-bottom, where it is associated with black clay. A zone within this interval ( 751 to 809 meters sub-bottom) has veins that consist of anhydrite and quartz and have black smectite linings. Apophyllite was found in association with anhydrite in Sample 504B-61-1, $55-60 \mathrm{~cm}$.

Pores filled with green clay are present all through the basalt section. To a depth of 527 meters sub-bottom, the clay is light green in color; below that depth it is darker. In Sample 504B-32-2, phillipsite was found in pores with the clay. The texture of smectite in a pore is shown in Plate 2, Figure 6.

\section{PHYSICAL AND CHEMICAL CONDITIONS FOR THE FORMATION OF SECONDARY MINERALS}

The composition of the secondary minerals recovered from the Costa Rica Rift basalts indicates that they originated mainly under alkaline conditions. Acidic conditions probably prevailed only in the lowest part of the basalt section, where pyrite and quartz are present.

The secondary minerals that form under nonoxidizing conditions are the most common in the Costa Rica Rift basalts. Trioctahedral smectite and (in the lower part of the section) pyrite are the most reliable indicators of these conditions.

Saponite formed in the basalt groundmass under the influence of the "autoclave" effect. Bass (1976) showed that smectite can form in the groundmass of basalts in a closed system with low oxygen activity and high $\mathrm{pH}$ values. His results were confirmed when saponite was produced during the experimental alteration of glassy basalt by hot seawater under closed and semiclosed conditions (Bischoff and Dickson, 1975; Hajash, 1975; Kotov et al., 1978; Mottl and Holland, 1978; Kholodkevich et al., 1981).

The conditions for the formation of smectite in the basalt pores are like the conditions in the basalt groundmass. The main mineral in the pores is saponite.

Although most of the secondary minerals formed under non-oxidizing conditions, the mineral assemblages in the upper part of the section of the Costa Rica Rift basalt (in the interval from 278 to 570 meters) indicate that there oxidizing conditions prevailed. Of prime importance in drawing this conclusion is the presence of hematite, together with traces of dioctahedral smectite; the latter is most likely $\mathrm{Fe}$-smectite. The phillipsite associated with these minerals can form under oxidizing conditions, as it has in the recent pelagic sediment of the Pacific. This mineral association differs from that determined for the oxidizing diagenesis of either the recent basalt of the East Pacific and Atlantic mid-oceanic ridges (Bass, 1976; Robinson et al., 1977; Seyfried et al., 1976,1978 ) or the ancient basalt from the Nauru Basin (Kurnosov et al., 1981), where the chief minerals of oxidative diagenesis are hydrous ferric oxides and celadonite. It should also be noted that the oxidative diagenesis in the Costa Rica Rift basalts is not as great in importance as in some other mid-oceanic ridges (e.g., those drilled during Legs 34 and 37). 
Temperature measurements near the base of Hole 504B (Becker et al., this volume) indicate that the highest temperature of formation of the secondary minerals in the Costa Rica Rift basalts did not exceed $120^{\circ} \mathrm{C}$. The temperature measured at the sediment/basalt contact is about $60^{\circ} \mathrm{C}$. Where smectites are present their temperature of formation can be inferred from the temperature of formation of the rest of the mineral assemblage. This temperature ranges from a high of about $100^{\circ} \mathrm{C}$ (where the smectite is associated with anhydrite and quartz) to a low of about $25^{\circ} \mathrm{C}$ (where the smectite is associated with hematite, cristobalite, pyrite, and phillipsite). The low temperature smectites are black clay, which occurs in the basalt groundmass and veins and formed during the initial stages of basalt heating, and light green and red brown clays, which were produced by oxidative diagenesis. The idea that the light green and red brown clays (as well as the black clays) formed at about $25^{\circ} \mathrm{C}$ is advanced by Seyfried et al. (1976 and 1978).

\section{SOURCES OF MATERIAL}

Experiments on basalt/seawater interaction (Bischoff and Dickson, 1975; Kotov et al., 1978; Mottl and Holland, 1978; Mottl et al., 1979; Kholodkevich et al., 1981) show that glassy tholeiitic basalt has all the components necessary for the formation of the secondary minerals identified in the Costa Rica Rift basalts. However, some endogenous components are also present in the Costa Rica Rift basalts (fluorine and potassium in apophyllite; sulfur in anhydrite, pyrite, and chalcocite; and $\mathrm{CO}_{2}$ in aragonite and calcite). Some of the secondary mineral cations also appear to be endogenous, especially in the lower part of the basalt section.

\section{HISTORY OF SECONDARY MINERAL FORMATION}

Pillow lava and submarine flows typically go through a deuteric stage of alteration and halmyrolysis and then reheat as basalts pile up. In the pillow lavas of the Costa Rica Rift, the deuteric stage and halmyrolysis did not produce secondary minerals (or at least none that have survived subsequent alteration). Studies of certain oceanic basalts (Kurnosov et al., 1978) show that secondary minerals do not necessarily form in glassy crusts in the deuteric stage or during long contact with cool sea water (halmyrolysis). Furthermore, no minerals formed in the pillow lava glassy crusts during the deuteric stage of halmyrolysis under oxidizing conditions. This observation disagrees with Bass's (1976) view that oxidative diagenesis occurs during the initial stages of basalt cooling.

The deuteric stage may however be of great importance for the formation of secondary minerals in the sills and thick flows (tens of meters) when seawater penetrates the solidifying lava slowly. Such deuteric minerals were reported in the Nauru Basin basalts recovered during Leg 61 (Kurnosov et al., 1981).

The secondary minerals in the Costa Rica Rift basalts formed later, while the basalts were being reheated. The reheating was rapid because this zone is relatively hot (the temperature measured at the sediment/basalt contact in the Hole 504B was about $60^{\circ} \mathrm{C}$ [Becker et al., this volume]). Early during this reheating, while tempera- tures were still relatively low, saponite grew in fractures and pores, replaced basalt groundmass material, and fragmented glassy crusts. Material for the formation of saponite was produced by basalt/seawater interaction.

A further increase in temperature toward the lower part of the section resulted in vein mineralization, with three assemblages appearing from the base upward: anhydrite-quartz with apophyllite; zeolite; and aragonite. Gray clay veins formed within the aragonite zone. The black clay that comprises the vein linings formed at higher temperatures than the black clay that formed during the first stages of the reheating of the basalt. Low temperature saponite clay remained stable during the temperature increase.

The mineral zones identified reflect the temperature facies of hydrothermal alteration. The source of $\mathrm{F}, \mathrm{CO}_{2}$, and part of the $\mathrm{S}$, as well as a number of cations, such as $\mathrm{K}$ in apophyllite, was endogenous.

The appearance of such high temperature minerals as talc, actinolite, and chlorite in the upper part of the section breaks the temperature zonation. Bismutite, which experiments have shown to form at $400-500^{\circ} \mathrm{C}$ (Mottl and Holland, 1978), was identified in the same part of the section.

The occurrence of these high temperature minerals in an otherwise low temperature zone can be explained by the different degree of saturation of the solutions with cations in the upper and lower parts of the basalt. With a sufficient degree of saturation temperature need not be so high.

The second type of zonation identified in the Costa Rica Rift basalts, which is based on the distribution of pyrite and hematite in the section, corresponds to the transition from nonoxidizing to oxidizing conditions. This boundary lies approximately 570 meters below the seafloor and 300 meters below the sediment/basalt interface. Oxidative diagenesis occurred during the final stage of secondary mineral formation, when tectonic movements caused old fractures to reopen and new ones to originate. New seawater, rich in oxygen, penetrated these fractures. Oxidative diagenesis manifested itself by the appearance of hematite, which was followed by the formation of phillipsite and of red brown, light green, and yellow brown clays. These rare minerals, which form under oxidizing conditions, are superposed on all other mineral assemblages to a sub-bottom depth of 570 meters.

The participants in Legs 69 and 70 noted both normal and reverse zonation in the distribution of clays in basalt veins. This can be accounted for not only by $\mathrm{pH}$ behavior but by the reopening of previously healed fractures. The rarity of hematite, phillipsite, and light green and yellow brown clays in the basalt section results from the fact that old fractures did not reopen everywhere.

The minerals that result from oxidative diagenesis in the Costa Rica Rift differ from those identified in some other mid-ocean ridges (Bass, 1976; Robinson et al., 1977 ) in that potassium is present in phillipsite instead of celadonite and nearly all $\mathrm{Fe}^{+3}$ is fixed in hematite.

A comparison of secondary minerals and the conditions of their formation in the Cretaceous off-ridge magmatic complex of the Nauru Basin (Kurnosov et al., 1981) 
with the Cenozoic pillow lavas of the Costa Rica Rift shows that the lava eruption mechanism determines the timing of the initial stage of secondary mineral formation in basalts and the composition of the resulting minerals. The eruption of thick flows and the intrusion of sills during Nauru Basin magmatism were immediately followed by the formation of secondary minerals - that is, the minerals formed during the deuteric stage. Where thin flows and pillow lavas have erupted, secondary minerals do not form in the deuteric stage but begin to originate during a later stage of heating. Therefore, during the formation of off-ridge basement in Cretaceous Nauru Basin (Shcheka, 1981; Shcheka and Kurenzova, in press), the conditions of secondary mineral formation and those of cation flux into the ocean and sediments were probably different from those at the Costa Rica Rift.

\section{CONCLUSIONS}

Secondary minerals in tholeiitic basalts of the Costa Rica Rift were formed by seawater/basalt interaction and endogenous element addition during the heating of the pillow lavas. The secondary minerals formed mainly under reducing alkaline conditions over a wide temperature interval. An acidic regime for secondary mineral formation was identified in the lower parts of the section.

Two types of zonation in vein mineralization were identified in the distribution of the secondary minerals in the basalt section: hydrothermal zonation and oxidative-nonoxidative zonation.

An interesting phenomenon is the occurrence of high temperature minerals in the upper part of the section and their absence in the lower part. We explain this by the different degree of saturation of the solutions with dissolved cations in the upper and lower parts of the basalt section.

Oxidative diagenesis manifested itself in the final stages of secondary mineral formation to a sub-bottom depth of 300 meters. The oxidative mineral assemblages differ from those known in some other portions of the midocean ridges in the absence of celadonite and the presence of phillipsite. The minerals formed during this stage of alteration are less abundant than those formed under nonoxidizing conditions in the Costa Rica Rift.

\section{ACKNOWLEDGMENTS}

We thank Dr. P. Robinson and Dr. E. Lelikov for reviewing the manuscript, and T. Bortina, G. Yudina, N. Ryapolova, V. Piskunova, and L. Kovbas for analytical work and helping to put the manuscript into shape.

\section{REFERENCES}

Bass, M. N., 1976. Secondary minerals in oceanic basalt, with special reference to Leg 34, Deep Sea Drilling Project. In Yeats, R. S., Hart, S. R., et al., Init. Repts. DSDP, 34: Washington (U.S. Govt. Printing Office), 393-432.

Bischoff, J. L., and Dickson, F. W., 1975. Seawater-basalt interaction at $200^{\circ} \mathrm{C}$ and 500 bars: implications for origin of sea-floor heavymetal deposits and regulation of seawater chemistry. Earth Planet. Sci. Lett., 25:385-397.

Hajash, A., 1975. Hydrothermal processes along mid-ocean ridges: an experimental investigation. Contrib. Mineral. Petrol., 53:205-226.

Joint Committee on Powder Diffraction Standards, 1974. Selected Powder Diffraction Data for Minerals (1st ed.): Swarthmore, Pa.

Kholodkevich, I. V., Kotov, N. V., and Kurnosov, V. B., 1981. Experimental study of secondary changes of volcanic glassy rocks in pure and model sea water at higher P-T parameters. In Mineral Transformations of Rocks of the Oceanic Substratum (Epigenesis and Initial Metamorphism): Moscow (Nauka), pp. 67-72.

Kotov, N. V., Kurnosov, V. B., and Kholodkevich, I. V., 1978. Modeling of natural volcanic rock alterations in pure and standard seawater at higher P-T values. Lithol. Mineral Res., 13:450-459. (Translated from Litologiya i Poleznye Iskopaemye, 1978, No. 4, pp. 78-89.)

Kurnosov, V. B., Kholodkevich, I. V., and Shevchenko, A. Ya., 1981. Secondary minerals of basalts from the Nauru Basin, Deep Sea Drilling Project Leg 61. In Larson, R. L., Schlanger, S. O., et al., Init. Repts. DSDP, 61: Washington (U.S. Govt. Printing Office), 653-671.

Kurnosov, V. B., Skornyakova, N. S., Murdmaa, I. O., Kashintsev, G. A., Narnov, G. A., and Shevchenko, A. Ya., 1978. Underwater weathering of glassy basalts on the ocean floor. Lithol. Mineral Res., 13:113-121. (Translated from Litologiya i Poleznye Iskopaemye, 1978, No. 1, pp. 134-143.)

Mottl, M. J., and Holland, H. D., 1978. Chemical exchange during hydrothermal alteration of basalt by seawater-I. Experimental results for major and minor components of seawater. Geochim. Cosmochim. Acta, 42:1103-1115.

Mottl, M., Holland, H. D., and Corr, R. F., 1979. Chemical exchange during hydrothermal alteration of basalt by seawater-II. Experimental results for $\mathrm{Fe}, \mathrm{Mn}$, and sulfur species. Geochim. Cosmochim. Acta, 43:869-884.

Robinson, P. T., Flower, M. F. J., Schminke, H.-U., and Ohnmacht, W., 1977. Low temperature alteration of oceanic basalts, DSDP Leg 37. In Aumento, F., Melson, W. G., et al., Init. Repts. DSDP, 37: Washington (U.S. Govt. Printing Office), 775-793.

Seyfried, W. E., Shanks, W. C., and Bischoff, J. L., 1976. Alteration and vein formation in Site 321 basalts. In Yeats, R. S., Hart, S. R., et al., Init. Repts. DSDP, 34: Washington (U.S. Govt. Printing Office), 385-392.

Seyfried, W. E., Jr., Shanks, W. C., III, and Dibble, W. E., Jr., 1978. Clay mineral formation in DSDP Leg 34 basalt. Earth. Planet. Sci. Lett., 41:265-276.

Shcheka, S., 1981. Igneous rocks of Deep Sea Drilling Project Leg 61, Nauru Basin. In Larson, R. L., Schlanger, S. O., et al., Init. Repts. DSDP, 61: Washington (U.S. Govt. Printing Office), 633-646.

Shcheka, S. A., and Kurenzova, N. A., in press. Magmatic complexes of the ocean. Soviet Geology. 

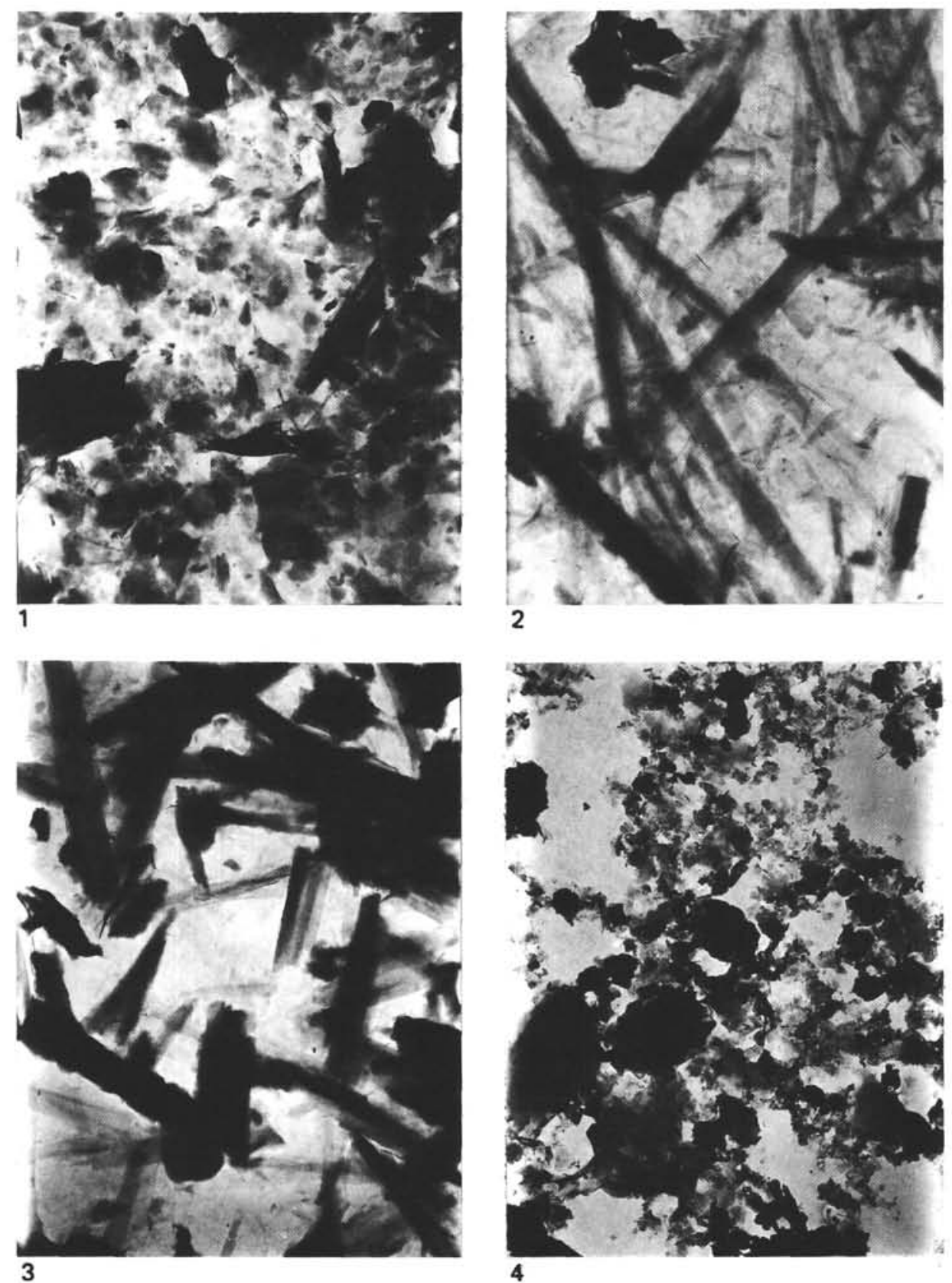

Plate 1. Electron micrographs of saponites from Leg 69 and 70 basalts. 1. Saponite from basalt groundmass, $\times 8000$; Sample 504B-70-1, 17-20 $\mathrm{cm}$ (size is $<2 \mu \mathrm{m}$ ). 2 to 4 . Saponite from veins. (2) Gray clay. Sample 504B-10-3, 17-20 cm; $\times 7000$. (3) Light green clay. Sample 504B-5-2, $142-146 \mathrm{~cm} ; \times 7000$. (4) Red brown clay. Sample 504B-2-1, 108-110 cm; $\times 12,000$. 

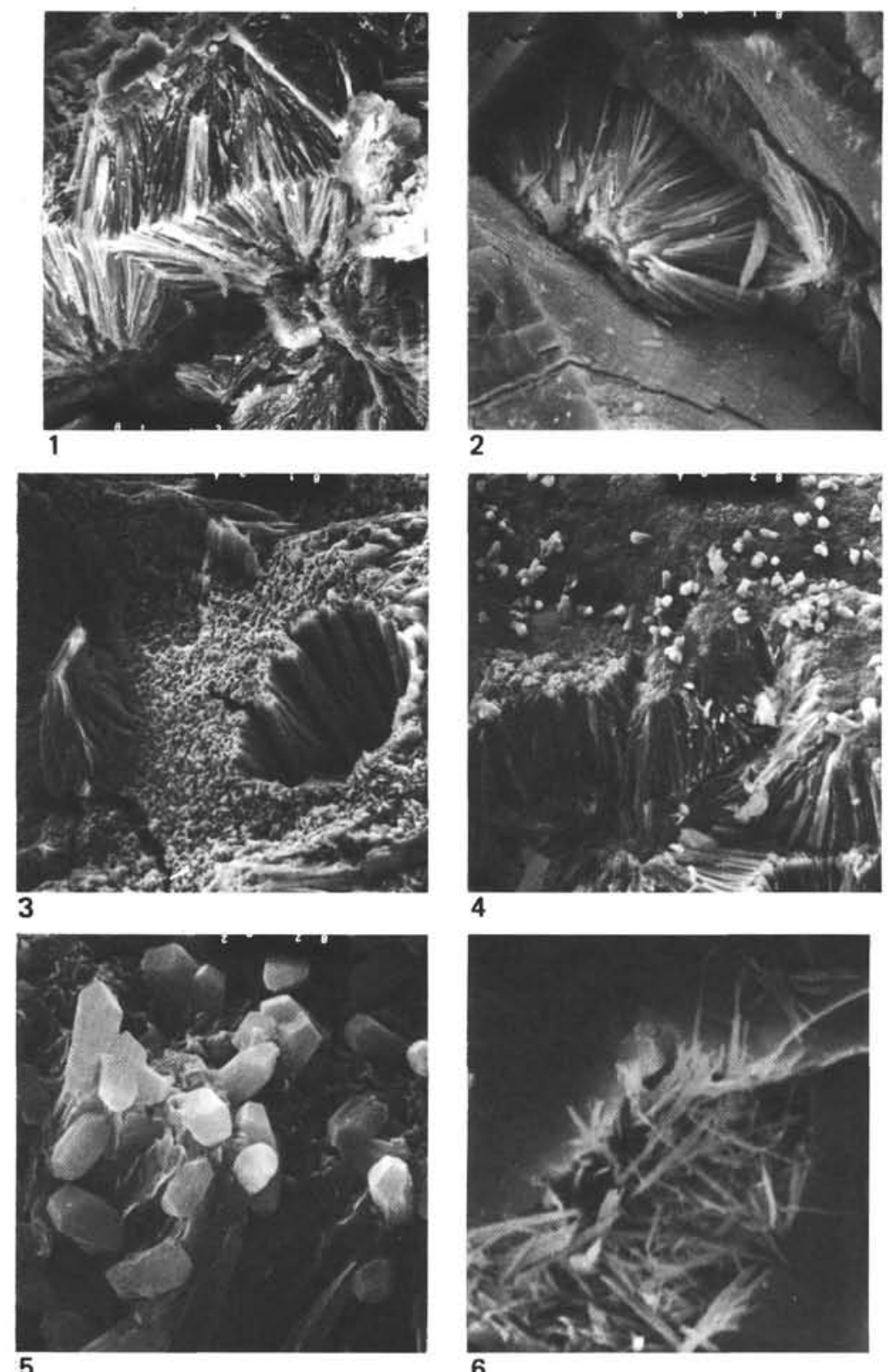

Plate 2. Electron micrographs of minerals from Leg 69 and 70 basalts. 1 . Gray clay, $\times 300$; Sample $504 \mathrm{~B}-7-2,64-68 \mathrm{~cm}$. 2 . Gray clay in basalt, $\times$ 500; Sample 504B-9-1, 142-147 cm. 3. Dark green clay with a silk luster, $\times 300$; Sample 504B-10-3, 17-20 cm. 4. Phillipsite on the gray clay, $\times$ 300; Sample 504B-9-1, 142-147 cm. 5. Same sample, $\times 3000$. 6. Smectite(?) in basalt, $\times 1500$; Sample 504B-37-1, 55-60 cm. 

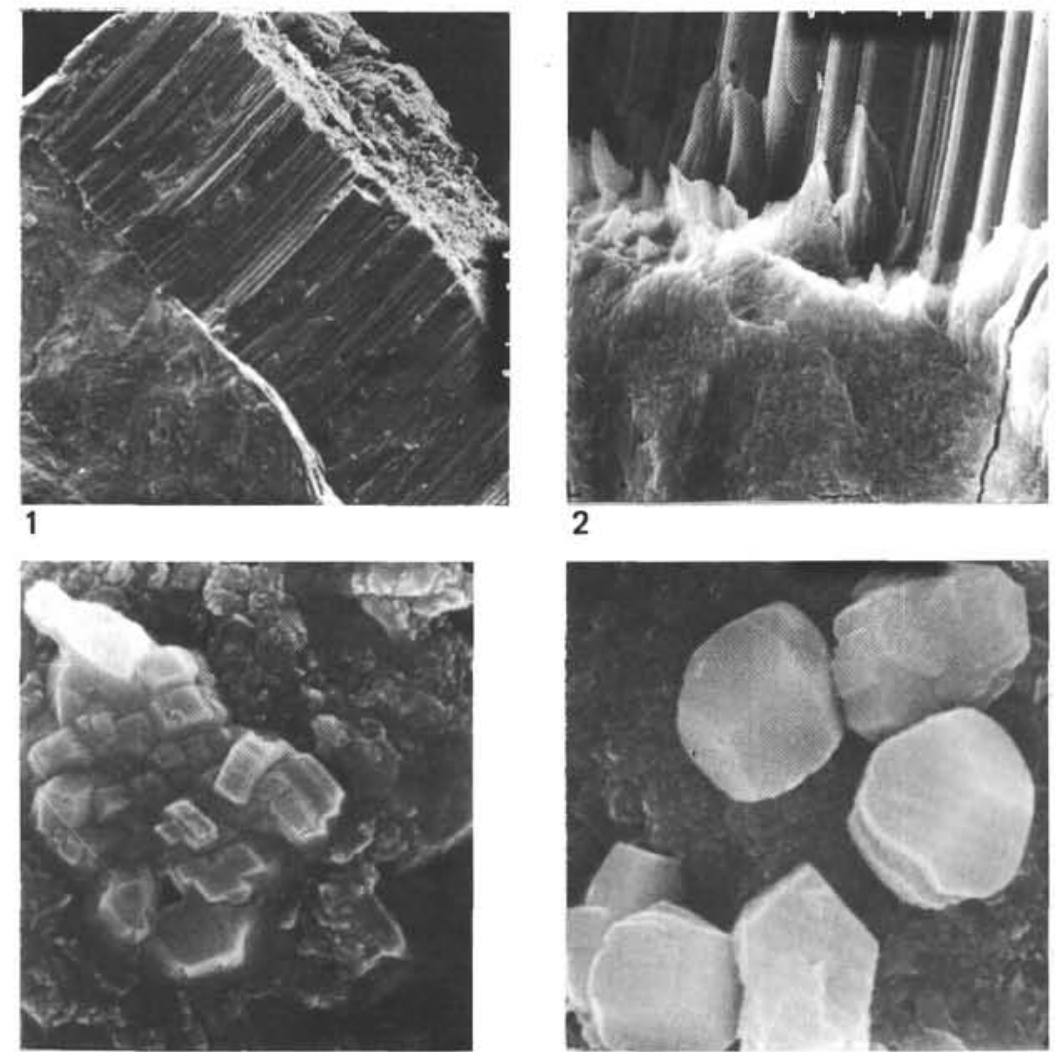

3
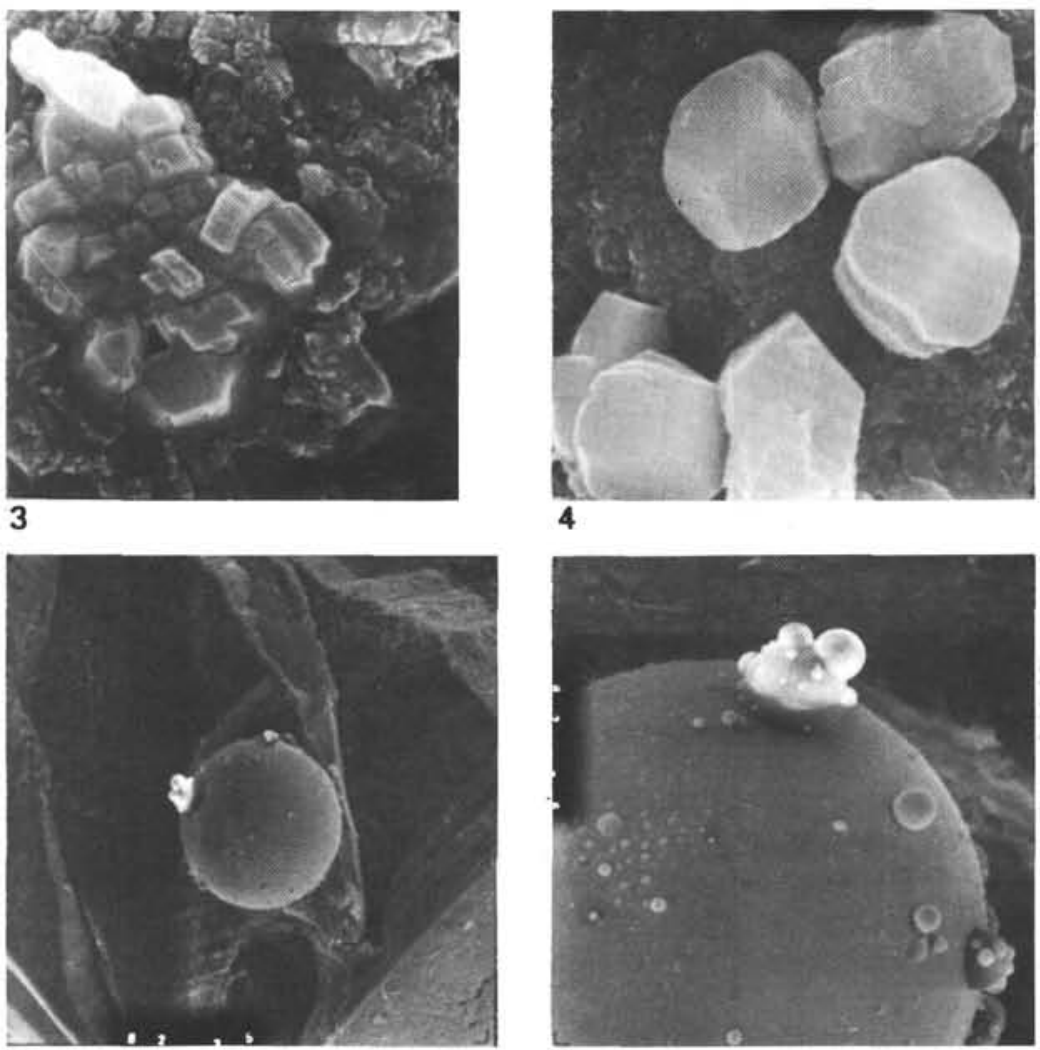

5

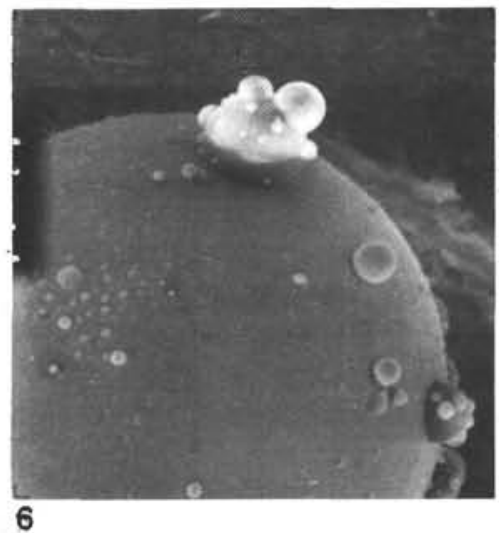

Plate 3. Electron micrographs of minerals from Leg 69 and 70 basalts. 1 . Vein aragonite in basalt, $\times 50$; Sample 501-15-3, 134-136 cm. 2 . Same sample, $\times 1500$. 3. Pyrite in black clay, $\times 4500$; Sample 504B-61-2, 145-149 cm. 4. Pyrite in black clay, $\times 5000$; Sample 504B-70-1, $17-20 \mathrm{~cm}$. 5. Nondetermined sphere on the pyrite, $\times 300$; Sample 504B-61-1, 55-60 cm. 6. Same sample, $\times 1000$. 